\title{
Elution study of acrylic monomers from orthodontic materials using high performance liquid chromatography (HPLC)
}

\author{
B. J. Kux ${ }^{1}$ L. M. Bacigalupo ${ }^{1}$ A. Scriba' ${ }^{1}$ M. Emmrich ${ }^{1}$ P.-G. Jost-Brinkmann' \\ Received: 4 November 2019 / Accepted: 6 February 2021 / Published online: 14 April 2021 \\ (c) The Author(s) 2021
}

\begin{abstract}
Purpose Main goal of the study was the identification and quantitative analysis of monomer elution from materials commonly used in fixed orthodontic therapy. Studies have shown severe health effects of monomers including cytotoxic, allergenic or mutagenic potential and endocrine changes. This in vitro study focusses primarily on five resins which are usually processed intraorally and remain in the oral cavity long-term.

Methods We tested the elution of monomers from specimens $(7.5 \mathrm{~mm} \times 1.5 \mathrm{~mm})$ immersed in artificial saliva at body temperature $\left(37^{\circ} \mathrm{C}\right)$ for $30 \mathrm{~min}$ to 5 weeks. The used method is in accordance with DIN EN ISO 10993-13. The five tested materials were BrackFix ${ }^{\circledR}$ (Voco GmbH, Cuxhaven, Germany), Triad ${ }^{\circledR}$ Gel (DeguDent GmbH, Hanau, Germany), and Transbond ${ }^{\mathrm{TM}}$ XT, LR and Plus (3M Unitek, Monrovia, CA, USA). All aliquots were analyzed using high performance liquid chromatography (HPLC). Data were statistically analyzed.

Results All five analyzed materials eluted substances over a period of 5 weeks. Identified substances included bisphenol A (BPA), triethylene glycol dimethacrylate (TEGDMA) and urethane dimethacrylate (UDMA). BPA eluted from Transbond ${ }^{\mathrm{TM}}$ Plus, XT, LR and BrackFix ${ }^{\circledR}$. The cumulated mean values after 35 days ranged from 16.04 to 64.83 ppm, depending on the material. TEGDMA eluted with a mean of $688.61 \mathrm{ppm}$ from Transbond ${ }^{\mathrm{TM}}$ LR. UDMA with a mean of $1682.00 \mathrm{ppm}$ from Triad ${ }^{\circledR}$ Gel. For each material the highest concentrations of all these substances were found in the first elution period. Other substances that were not equivocally identified or of low concentration also eluted.

Conclusion Using the described method, it is possible to qualitatively and quantitatively determine the in vitro elution of monomers from orthodontic materials. The concentrations of the substances identified were below the current maximum recommended intake. However, a cumulative effect and low-dose effects should be considered for both patients and dental professionals, especially for young patients. Measures to reduce exposure patients and practitioners are suggested.
\end{abstract}

Keywords Bisphenol A-glycidyl dimethacrylate · Triethylene glycol dimethacrylate · Urethane dimethacrylate · Adhesives · Orthodontic appliances, fixed

\section{Untersuchung zur Freisetzung von Monomeren aus acrylhaltigen Materialien in der Kieferorthopädie mittels Hochleistungsflüssigkeitschromatographie (HPLC)}

\section{Zusammenfassung}

Ziel Das übergeordnete Ziel dieser Untersuchung war die qualitative und quantitative Untersuchung gebräuchlicher kieferorthopädischer Materialien hinsichtlich ihrer Monomerfreisetzung. Studien haben erhebliche gesundheitliche Auswirkungen von Monomeren nachgewiesen, etwa ihr zytotoxisches, allergenes bzw. mutagenes Potenzial und endokrine Veränderungen. Diese In-vitro-Studie konzentriert sich vor allem auf 5 Kunststoffe, die in der Regel intraoral verarbeitet werden und langfristig dort verbleiben.

Shared conference award 2018 for the best lecture of a junior scientist at the 91 st annual meeting of the DGKFO in Bremen, Germany.

\section{B. J. Kux}

kfo@charite.de
Institute of Dental, Oral and Maxillary Medicine, Department of Orthodontics, Dentofacial Orthopedics and Pedodontics, Charité-Universitätsmedizin Berlin, Corporate Member of Freie Universität Berlin and Humboldt-Universität zu Berlin, Aßmannshauser Str. 4-6, 14197 Berlin, Germany 
Methoden Untersucht wurde die Freisetzung von Monomeren aus Proben $(7.5 \mathrm{~mm} \times 1.5 \mathrm{~mm})$, die bei Körpertemperatur $\left(37^{\circ} \mathrm{C}\right)$ für $30 \mathrm{~min}$ bis 5 Wochen in künstlichen Speichel getaucht wurden. Die dabei verwendete Methode ist konform mit DIN EN ISO 10993-13. Die 5 getesteten Materialien waren BrackFix ${ }^{\circledR}$ (Voco GmbH, Cuxhaven), Triad ${ }^{\circledR G e l}$ (DeguDent GmbH, Hanau) und Transbond ${ }^{\mathrm{TM}}$ XT, LR und Plus (3M Unitek, Monrovia/CA, USA). Alle Aliquots wurden mit Hochleistungsflüssigkeitschromatographie (HPLC) analysiert.

Ergebnisse Alle 5 analysierten Materialien eluierten Substanzen über einen Zeitraum von 5 Wochen. Zu den identifizierten Substanzen gehörten Bisphenol A (BPA), Triethylenglykol-Dimethacrylat (TEGDMA) und Urethan-Dimethacrylat (UDMA). BPA wurde aus Transbond ${ }^{\mathrm{TM}}$ Plus, XT, LR und BrackFix ${ }^{\circledR}$ eluiert. Die kumulierten Mittelwerte nach 35 Tagen reichten je nach Material von 16,04-64,83 ppm. TEGDMA eluierte mit einem Mittelwert von 688,61 ppm aus Transbond ${ }^{\mathrm{TM}}$ LR, UDMA mit einem Mittelwert von 1682,00 ppm aus Triad ${ }^{\circledR}$ Gel. Höchstwerte im Verhältnis von Menge zur Zeit der freigesetzten Substanzen wurden für jedes Material in der initialen Periode ermittelt. Weitere, nicht identifizierte sowie gering konzentrierte Substanzen wurden ebenfalls eluiert. Für jedes Material wurden die höchsten Konzentrationen all dieser Substanzen in der ersten Elutionsperiode gefunden. Andere Substanzen, die nicht eindeutig identifiziert wurden oder von geringer Konzentration waren, wurden ebenfalls eluiert.

Schlussfolgerung Mit der beschriebenen Methode ist es möglich, die In-vitro-Elution von Monomeren aus kieferorthopädischen Materialien qualitativ wie quantitativ zu bestimmen. Die Konzentrationen der identifizierten Substanzen lagen unterhalb der derzeit empfohlenen maximalen Aufnahmemenge. Dennoch sollten eine kumulative Wirkung und Niedrigdosiseffekte sowohl für Patienten, vor allem für junge Patienten, als auch für das zahnärztliche Personal in Erwägung gezogen werden. Maßnahmen zur Verringerung der Exposition von Patienten und Behandelnden werden vorgeschlagen.

Schlüsselwörter Bisphenol-A-Glycidyl-Dimethacrylat · Triethylenglykol-Dimethacrylat • Urethan-Dimethacrylat . Klebstoffe · Festsitzende kieferorthopädische Apparaturen

\section{Introduction}

An orthodontic treatment requires various materials for removable and fixed appliances. The period of time orthodontic appliances stay in the oral cavity ranges from minutes to several years, where environmental influences affect the materials' durability and biodegradation. Important variables include thermal and $\mathrm{pH}$ value changes, enzymatic and bacterial activity, or mechanical alteration. For example, food, saliva, muscular activity and the stress from dimensional changes cause extreme conditions for any material.

Besides different metal alloys and ceramics, various resins with similar composition to dental fillings are frequently used for multiple appliances and purposes in treatments. In orthodontics, acrylic monomers are for example found in aligners, removable appliances such as functional appliances or removable retainers or as bonding material between teeth and brackets or lingual retainers.

The chemical composition of dental and orthodontic resins and polymers can be divided into three major components. Namely, an organic phase, a disperse phase with inorganic fillers determining mechanical and physical properties, and a bonding phase or coupling agent. Characteristics like viscosity or shrinkage during polymerization differ due to this composition. The organic phase contains monomers, oligomers, initiators, inhibitors and other additives. Main representatives of the monomers are substances with high molecular weight for less shrinkage like bis-GMA (bisphenol A glycidyl dimethacrylate) and
UDMA (urethane dimethacrylate) or low-molecular-weight substances for improved flowability such as HEMA (2hydroxyethyl methacrylate) and TEGDMA (triethylene glycol dimethacrylate) [2, 22, 40].

Several articles have investigated common monomers in orthodontics. Especially BPA (bisphenol A), used as a starter ingredient for bis-GMA or bis-EMA (ethoxylated bisphenol A dimethacrylate), but also others like TEGDMA and UDMA were in the focus of researchers [17, 19, 34, $36,45,48]$.

Since these polymers never reach a full degree of conversion after photo- or self-curing polymerization, residual and leaching monomers from methacrylate-based restorative and orthodontic materials are seen as a result $[5,21$, 23]. These substances have been found in different tissues and fluids [3, 4, 35, 37, 46, 54], causing allergic [18, 28], teratogenic $[46,49]$, cytotoxic $[7,12,16,20]$, mutagenic [14, 25, 41], neurotoxic [61], endocrine effects [38, 57], fertility disorders [29, 59] and DNA damage [47, 60] or epigenetic programming [44]. Furthermore, early exposure to monomers is suspected of causing molar incisor hypomineralization (MIH) and having an impact on the psychosocial health of children [24, 32, 33].

The European Food Safety Authority (EFSA) and the U.S. Food and Drug Administration (FDA) reacted to the scientific findings and set limits to a maximal daily intake of BPA in the past [13]. In 2015, the EFSA lowered the threshold from 50 to $4 \mu \mathrm{g} / \mathrm{kg}$ body weight/day. Since 2011 there has been a ban on BPA in baby bottles in the EU [8]; in 
2015 a complete ban on BPA from all food packaging was introduced in France, while other European countries added similar restrictions [6]. However, despite the many studies mentioned above which found local, systemic and synergistic effects of TEGDMA and UDMA, even in low doses, no thresholds exist, yet. Discussions about health threats and environmental issues from polymers are the reason for restrictions and an ongoing controversy. Against this background it is also the responsibility of every orthodontist to use and seek alternatives to minimize potentially hazardous uptake of these substances from orthodontic materials.

In the present study we tested five frequently used acrylic based orthodontic light-curing resins with different indications: BrackFix ${ }^{\circledR}$ (BrackFix; Voco GmbH, Cuxhaven, Germany) and Transbond ${ }^{\mathrm{TM}}$ XT (Transbond ${ }^{\mathrm{TM}} \mathrm{XT}$; 3M Unitek, Monrovia, CA, USA) to bond metal and ceramic brackets to tooth surfaces, Transbond ${ }^{\mathrm{TM}}$ LR (Transbond ${ }^{\mathrm{TM}} \mathrm{LR}$; 3M Unitek, Monrovia, CA, USA) for bonding fixed lingual retainers, Transbond ${ }^{\mathrm{TM}}$ Plus (Transbond ${ }^{\mathrm{TM}}$ Plus; 3M Unitek, Monrovia, CA, USA) a band adhesive and $\operatorname{Triad}^{\circledR} \mathrm{Gel}$ (Tri-
adGel; DeguDent GmbH, Hanau, Germany) as a multipurpose material.

It was the aim of this in vitro investigation to study leakage of BPA, Bis-GMA, CQ (camphorquinone), HEMA, HQ (hydroquinone), MMA (methyl-methacrylate), TEGDMA, and UDMA using artificial saliva at body temperature as elution medium, analyzed by high performance liquid chromatography (HPLC).

\section{Materials and methods}

The five tested orthodontic materials and their compositions, instructions and test parameters are listed in Table 1.

Polyoxymethylene (POM) rings between two glass microscope slides were used to create ten identical disc-shaped samples $\left(7 \mathrm{~mm}\right.$ diameter, $1.5 \mathrm{~mm}$ thick, $76.97 \mathrm{~mm}^{2}$ exposed surface area, $57.73 \mathrm{~mm}^{3}$ volume) each of BrackFix ${ }^{\circledR}$, Triad ${ }^{\circledR}$ Gel, Transbond ${ }^{\mathrm{TM}}$ XT, Transbond ${ }^{\mathrm{TM}} \mathrm{LR}$ and Transbond ${ }^{\mathrm{TM}}$ Plus.

Table 1 Orthodontic materials and their compositions, instructions and test parameters

Tab. 1 Kieferorthopädische Materialien: Bestandteile, Anwendungshinweise und Prüfparameter

\begin{tabular}{|c|c|c|c|}
\hline $\begin{array}{l}\text { Product and } \\
\text { manufacturer }\end{array}$ & Composition from safety data sheets (if given: CAS No.) & $\begin{array}{l}\text { Polymerization } \\
\text { instructions }\end{array}$ & Test parameters \\
\hline $\begin{array}{l}\text { Triad }{ }^{\circledR} \text { Gel } \\
\text { DeguDent } \\
\text { GmbH, } \\
\text { Hanau, Ger- } \\
\text { many }\end{array}$ & $\begin{array}{l}\text { Urethane dimethacrylate (UDMA) } \\
\text { Silicon dioxide } \\
\text { Pigments } \\
\text { Initiators } \\
\text { Stabilizers }\end{array}$ & $\begin{array}{l}30 \mathrm{~s} \text { in } \\
\text { Triad }^{\circledR} 2000 \text { Light } \\
\text { Curing Unit } \\
\text { (Dentsply Interna- } \\
\text { tional, } \\
\text { York, PA, USA) }\end{array}$ & $\begin{array}{l}\text { Light intensity/time: } \\
1600 \mathrm{~mW} / \mathrm{cm}^{2} \text { for } 30 \mathrm{~s} \\
\text { Curing light distance: } \\
2 \mathrm{~mm} \\
\text { Mean sample weight: } \\
0.071 \mathrm{~g}\end{array}$ \\
\hline $\begin{array}{l}\text { Transbond }^{\mathrm{TM}} \\
\text { Plus } \\
\text { 3M Unitek, } \\
\text { Monrovia, } \\
\text { CA, USA }\end{array}$ & $\begin{array}{l}\text { Silane-treated glass } \\
\text { Glycerol 1,3-dimethacrylate (1830-78-0) } \\
\text { Citric acid dimethacrylate oligomer } \\
\text { Silane-treated silica (248596-91-0) } \\
\text { Diphenyliodonium hexafluorophosphate (58109-40-3) }\end{array}$ & $\begin{array}{l}\text { Light intensity/ } \\
\text { time: } \\
1600 \mathrm{~mW} / \mathrm{cm}^{2} \text { for } \\
30 \mathrm{~s} \\
\text { Curing light dis- } \\
\text { tance: } \\
1-2 \mathrm{~mm}\end{array}$ & $\begin{array}{l}\text { Light intensity/time: } \\
1600 \mathrm{~mW} / \mathrm{cm}^{2} \text { for } 30 \mathrm{~s} \\
\text { Curing light distance: } \\
1 \mathrm{~mm} \\
\text { Mean sample weight: } \\
0.129 \mathrm{~g}\end{array}$ \\
\hline $\begin{array}{l}\text { Transbond }^{\mathrm{TM}} \\
X T \\
\text { 3M Unitek, } \\
\text { Monrovia, } \\
\text { CA, USA }\end{array}$ & $\begin{array}{l}\text { Silane-treated quartz (10042-78-6) } \\
\text { Bisphenol A diglycidyl ether dimethacrylate (bis-GMA) (1565-94-2) } \\
\text { Bisphenol A bis(2-hydrocyethyl ether) dimethacrylate (24448-20-2) } \\
\text { Silane-treated silica (68611-44-9) } \\
\text { Diphenyliodonium hexafluorophosphate (5810940-3) }\end{array}$ & $\begin{array}{l}\text { Light intensity/ } \\
\text { time: } \\
1600 \mathrm{~mW} / \mathrm{cm}^{2} \text { for } \\
3 \mathrm{~s} \\
\text { Curing light dis- } \\
\text { tance: } \\
2-3 \mathrm{~mm}\end{array}$ & $\begin{array}{l}\text { Light intensity/time } \\
1600 \mathrm{~mW} / \mathrm{cm}^{2} \text { for } 3 \mathrm{~s} \\
\text { Curing light distance: } \\
2 \mathrm{~mm} \\
\text { Mean sample weight: } \\
0.133 \mathrm{~g}\end{array}$ \\
\hline $\begin{array}{l}\text { Transbond } \\
\text { LR } \\
\text { 3M Unitek, } \\
\text { Monrovia, } \\
\text { CA, USA }\end{array}$ & $\begin{array}{l}\text { 2-Propenoic acid, 2-methyl-, 3-(trimethoxysilyl)propyl ester, } \\
\text { reaction products with quartz (100402-78-6) } \\
\text { Bisphenol A diglycidyl ether dimethacrylate (bis-GMA) (1565-94-2) } \\
\text { Triethylene glycol dimethacrylate (TEGDMA) (109-16-0) } \\
\text { Dichlorodimethylsilane reaction product with silica (68611-44-9) } \\
\text { Ethyl-4-dimethylaminobenzoate (EDB) (10287-53-3) } \\
\text { Diphenyliodonium hexafluorophosphate (58109-40-3) }\end{array}$ & $\begin{array}{l}\text { Light intensity/ } \\
\text { time: } \\
1600 \mathrm{~mW} / \mathrm{cm}^{2} \text { for } \\
10 \mathrm{~s} \\
\text { Curing light dis- } \\
\text { tance: } \\
\text { not given }\end{array}$ & $\begin{array}{l}\text { Light intensity/time } \\
1600 \mathrm{~mW} / \mathrm{cm}^{2} \text { for } 10 \mathrm{~s} \\
\text { Curing light distance: } \\
2 \mathrm{~mm} \\
\text { Mean sample weight: } \\
0.140 \mathrm{~g}\end{array}$ \\
\hline $\begin{array}{l}\text { BrackFix } \\
\text { VOCO } \\
\text { GmbH, } \\
\text { Cuxhaven, } \\
\text { Germany }\end{array}$ & $\begin{array}{l}\text { Bis-GMA (1565-94-2) } \\
\text { Bis-EMA (41637-38-1) }\end{array}$ & $\begin{array}{l}\text { Light intensity/ } \\
\text { time: } \\
\text { min. } 1000 \mathrm{~mW} / \mathrm{cm}^{2} \\
\text { for } 20 \mathrm{~s} \\
\text { Curing light dis- } \\
\text { tance: } \\
1-2 \mathrm{~mm}\end{array}$ & $\begin{array}{l}\text { Light intensity/time: } \\
1200 \mathrm{~mW} / \mathrm{cm}^{2} \text { for } 20 \mathrm{~s} \\
\text { Curing light distance: } \\
1 \mathrm{~mm} \\
\text { Mean sample weight: } \\
0.135 \mathrm{~g}\end{array}$ \\
\hline
\end{tabular}


Table 2 HPLC: setup and parameters

Tab. 2 HPLC: Aufbau und Parameter

\begin{tabular}{|c|c|c|}
\hline & Model & Manufacturer \\
\hline Controller & SCL-10A VP & $\begin{array}{l}\text { Shimadzu, Kyoto, } \\
\text { Japan }\end{array}$ \\
\hline Pump A & LC-10AD VP & $\begin{array}{l}\text { Shimadzu, Kyoto, } \\
\text { Japan }\end{array}$ \\
\hline Pump B & LC-10AD VP & $\begin{array}{l}\text { Shimadzu, Kyoto, } \\
\text { Japan }\end{array}$ \\
\hline $\begin{array}{l}\text { Diode array } \\
\text { detector }\end{array}$ & SPD-M10A VP & $\begin{array}{l}\text { Shimadzu, Kyoto, } \\
\text { Japan }\end{array}$ \\
\hline Autosampler & SIL-10A & $\begin{array}{l}\text { Shimadzu, Kyoto, } \\
\text { Japan }\end{array}$ \\
\hline Column oven & CTO-10 AS VP & $\begin{array}{l}\text { Shimadzu, Kyoto, } \\
\text { Japan }\end{array}$ \\
\hline Column & $\begin{array}{l}\text { EC } 125 / 2 \text { Nucleosil } \\
100-5 \text { C18 Nautilus }\end{array}$ & $\begin{array}{l}\text { Macherey-Nagel, } \\
\text { Düren, Germany }\end{array}$ \\
\hline Degasser & Degasys DG-1210 & $\begin{array}{l}\text { UniFlows, Tokyo, } \\
\text { Japan }\end{array}$ \\
\hline Software & Class VP 4.7 & $\begin{array}{l}\text { Shimadzu, Kyoto, } \\
\text { Japan }\end{array}$ \\
\hline \multirow[t]{3}{*}{ Settings } & Mobile phase & $\begin{array}{l}\mathrm{C}_{2} \mathrm{H}_{3} \mathrm{~N} 90 \% \text {, aqua } \\
\text { dest. } 10 \%\end{array}$ \\
\hline & Detection & $200-340 \mathrm{~nm}$ \\
\hline & Flowspeed & $0.25 \mathrm{~mL} / \mathrm{min}$ \\
\hline
\end{tabular}

HPLC high pressure liquid chromatography

Every material was light-cured with a LED light-curing unit (VALO C0 1516 LED, Ultradent Products Inc., South Jordan, UT, USA), following the instructions provided by the manufacturers regarding light intensity, wavelength and polymerization time. Individually manufactured polymerization-stands for each material were used to keep the recommended distance from sample to curing light. The light unit was routinely tested by a photometer (Bluephase ${ }^{\circledR}$ Meter II; Ivoclar Vivadent AG, Schaan, Liechtenstein), the mean output was $1188 \mathrm{~mW} / \mathrm{cm}^{2}\left(1200 \mathrm{~mW} / \mathrm{cm}^{2}\right.$ mode) and $1604 \mathrm{~mW} / \mathrm{cm}^{2}\left(1600 \mathrm{~mW} / \mathrm{cm}^{2}\right.$ mode $)$, measured through a microscope slide.

Table 3 Monomers used in calibration standards

Tab. 3 Für die Kalibrierungsstandards verwendete Monomere

\begin{tabular}{|c|c|c|c|}
\hline Substance & Abbreviation & CAS No. & Manufacturer \\
\hline Hydroquinone & HQ & $123-31-9$ & Sigma-Aldrich $^{\mathrm{a}}$ \\
\hline 2-Hydroxyethyl methacrylate & HEMA & $868-77-9$ & Sigma-Aldrich $^{\mathrm{a}}$ \\
\hline Methyl methacrylate & MMA & $80-62-6$ & Sigma-Aldrich $^{\mathrm{a}}$ \\
\hline Camphorquinone & CQ & $10373-78-1$ & Sigma-Aldrich $^{\mathrm{a}}$ \\
\hline Triethylene glycol dimethacrylate & TEGDMA & $109-16-0$ & Sigma-Aldrich $^{\mathrm{a}}$ \\
\hline $\begin{array}{l}\text { Bisphenol A } \\
\text { (2,2-Bis(4-hydroxyphenyl)propane, } \\
\text { 4,4'-isopropylidenediphenol) }\end{array}$ & BPA & $80-05-7$ & Sigma-Aldrich $^{\mathrm{a}}$ \\
\hline Diurethane dimethacrylate & UDMA & $72869-86-4$ & Sigma-Aldrich $^{\mathrm{a}}$ \\
\hline Bisphenol A glycerolate dimethacrylate & Bis-GMA & $1565-94-2$ & Merz Dental $^{\mathrm{b}}$ \\
\hline
\end{tabular}

aSigma-Aldrich, St. Louis, MO, USA

${ }^{b}$ Merz Dental GmbH, Lütjenburg, Germany
Each sample was weighed and afterwards immersed in new glass sample vials with tetrafluoroethylene-lined caps (20 mL, GL 18, Duran ${ }^{\circledR}$, Schott AG, Mainz, Germany) to prevent contamination, containing $1.5 \mathrm{~mL}$ artificial saliva type Fusayama/Meyer (Pickering Laboratories, Inc., Mountain View, CA, USA). The POM ring was attached to a nylon string (diameter $0.16 \mathrm{~mm}$, folia, Max Bringmann KG, Wendelstein, Germany) allowing the tested materials to move freely in the medium. The glass tubes were placed on an individually manufactured circular tube tray, rotating at $60 \mathrm{rpm}$ by a shaker (3D Sunflower Mini Shaker, BioSan, Riga, Latvia) in an incubator (Heraeus, Hanau, Germany) at $+37^{\circ} \mathrm{C}$, simulating intraoral conditions.

In accordance with DIN EN ISO 10993-13, specimens of $1 \mathrm{~mL}$ of the test tubes (artificial saliva, POM ring, sample, nylon string) and a control tube (artificial saliva, POM ring, nylon string) were collected $30 \mathrm{~min}, 3 \mathrm{~h}, 6 \mathrm{~h}, 24 \mathrm{~h}, 48 \mathrm{~h}, 72 \mathrm{~h}$, 7 days, 14 days, 21 days, 28 days and 35 days after immersion (t1-t11). Each time, $1 \mathrm{~mL}$ of fresh artificial saliva was added to the glass tubes afterwards.

The specimens were stored at $+4^{\circ} \mathrm{C}$ in HPLC vials to prevent contamination or reactions with monomers or other substances. In addition, the experiments were performed in a laboratory protected from UV light. All aliquots were analyzed by high performance liquid chromatography (HPLC). The setup and settings are listed in Table 2. The monomers and calibration standards in methanol are summarized in Table 3. The detection of the monomers in the specimens was based on the retention time and the spectrum given by the calibration standards and the quantification by the area under the curve (AUC) of each sample and standard. Four monomer-standards were analyzed during each HPLC run. One in artificial saliva and another one in distilled water, each before and after measuring the specimen to identify possible differences in the retention time and peak appearance. To minimize error sources, all procedures and an individual control of every chromatogram were performed by the same investigator (first author), including baseline 
Fig. 1 Chromatogram of a monomer standard in artificial saliva with assignment of the peaks. Monomer abbreviations provided in Table 3

Abb. 1 Chromatogramm eines Monomerstandards in künstlichem Speichel mit Zuweisung der Peaks. Abkürzungen für Monomere s. Tab. 3

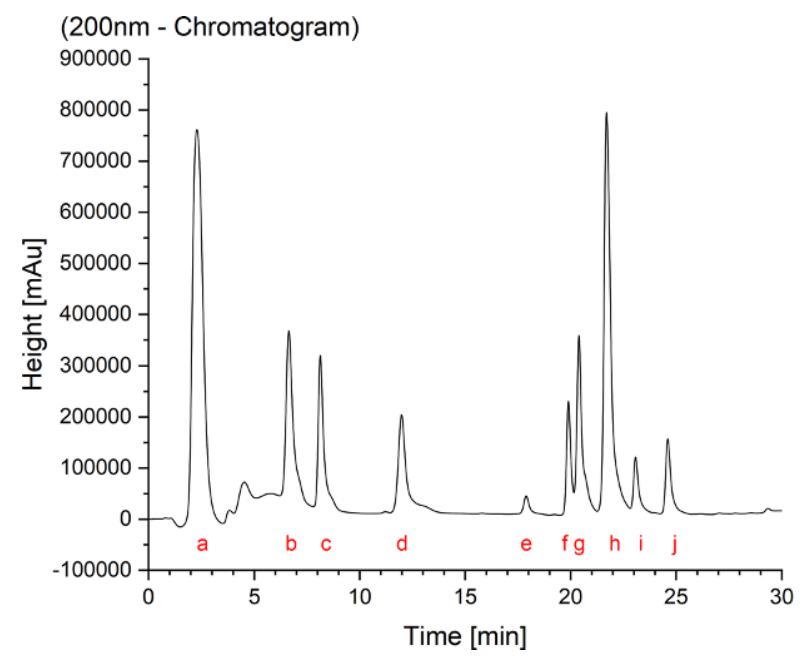

adaptions, the identification of split peaks, fronting, tailing or other deviations in the chromatograms.

The obtained data for the BPA release from four materials was analyzed with a two-way analysis of variance (ANOVA) to evaluate the impact of time and different materials on the elution process. The $p$ value of the interaction analysis has to be considered as exploratory due to the nature of the evaluation.

The following software were used for data processing and visualization: Class VP 4.7 (Shimadzu, Kyoto, Japan), Excel $^{\circledR}$ for Mac 16.23 (Microsoft, Redmond, WA, USA), SPSS ${ }^{\circledR}$ Statistics 26 (IBM, Armonk, NY, USA) and OriginPro 2019 (OriginLab, Northampton, MA, USA).

\section{Results}

The final chromatograms made an analysis of the standards, control group and specimens possible (Fig. 1). All five materials released monomers and other not uniquely identifiable substances (Table 4). Samples with a $76.97 \mathrm{~mm}^{2}$ surface area and $57.73 \mathrm{~mm}^{3}$ volume were immersed in $1.5 \mathrm{~mL}$. The mean weight of the samples was $0.071 \mathrm{~g}$ (Triad $\left.{ }^{\circledR} \mathrm{Gel}\right)$, $0.129 \mathrm{~g}$ (Transbond ${ }^{\mathrm{TM}}$ Plus), $0.133 \mathrm{~g}$ (Transbond $^{\mathrm{TM}} \mathrm{XT}$ ), $0.14 \mathrm{~g}$ (Transbond $^{\mathrm{TM}} \mathrm{LR}$ ) and $0.135 \mathrm{~g}$ (BrackFix $\left.^{\circledR}\right)$. The minimum detection threshold for the identification and quantification of peaks in the chromatograms was set to the area under curve (AUC) value of 100,000 in ClassVP 4.7.

It was possible to identify and quantify BPA, UDMA and TEGDMA by their retention time and spectrum (Table 4, Figs. 2, 3, 4, 5, 6 and 7). Other peaks were found, either below the threshold or not matching with monomers used in the standards for calibration.

Triad ${ }^{\circledR}$ Gel eluted UDMA with a cumulative mean of $1682.00 \pm 262.07 \mathrm{ppm}$ after 35 days (t0-t11). It is the highest cumulative mean of a substance detected in the study.
The highest elution occurred between $\mathrm{t} 3$ and $\mathrm{t} 4$ (6-24 $\mathrm{h}$ after immersion) with a mean of $229.41 \mathrm{ppm}$, while the lowest value was observed between 28 and 35 days (t10-t11) with a mean of $99.54 \mathrm{ppm}$ (Fig. 2). No significant amounts of other unknown peaks were found in the chromatograms.

Transbond ${ }^{\mathrm{TM}}$ Plus eluted BPA and two not uniquely identified substances. A cumulative mean of $14.44 \pm 1.84 \mathrm{ppm}$ BPA after 35 days was detected. A maximum peak with a mean of $9.37 \mathrm{ppm}$ at $\mathrm{t} 1$ (after $30 \mathrm{~min}$ ) and a minimum mean of $0.73 \mathrm{ppm}$ at $\mathrm{t} 11$ (Fig. 3). The unidentified peaks showed retention times similar to the retention times in our standards of hydroquinone and camphorquinone. Both, just as BPA, are not mentioned in the safety data sheets provided by the manufacturer.

Transbond $^{\mathrm{TM}}$ XT eluted a cumulative mean of $64.83 \pm 5.58 \mathrm{ppm}$ BPA after 35 days, a maximum mean of $9.37 \mathrm{ppm}$ at $\mathrm{t} 4$, a minimum (3.91 ppm) at $\mathrm{t} 1$ (Fig. 4). It is the highest cumulative mean of BPA from all the tested materials. Smaller peaks of bis-GMA below the threshold were also identified.

Transbond $^{\mathrm{TM}}$ LR eluted TEGDMA and BPA. TEGDMA eluted the second highest cumulative mean of the study with $688.61 \pm 185.40$ ppm after 35 days, an elution maximum with a mean of 208.87 after $30 \mathrm{~min}(\mathrm{t} 1)$ and a minimum of $8.32 \mathrm{ppm}$ at $\mathrm{t} 11$ (Fig. 5). The cumulative mean of BPA was $18.46 \pm 9.49$ ppm after the 35 days, the maximum elution was measured at $\mathrm{t} 1$ with $2.45 \mathrm{ppm}$ and a minimum of $1.09 \mathrm{ppm}$ at t10 (Fig. 6).

BrackFix ${ }^{\circledR}$ eluted $19.44 \pm 1.91$ ppm of BPA in 35 days. The maximum mean was at $\mathrm{t} 4$ with $2.74 \mathrm{ppm}$, the minimum at $\mathrm{t} 2$ was $1.38 \mathrm{ppm}$ (Fig. 7). Smaller peaks of bis-GMA under the set threshold were also identified.

For every tested material and identified substance, the average amount of the eluted substances in ppm per hour showed a maximum for the values of $\mathrm{t} 1(0-30 \mathrm{~min})$ and a minimum at t11 (28-35 days interval; Figs. 8, 9 and 10). 


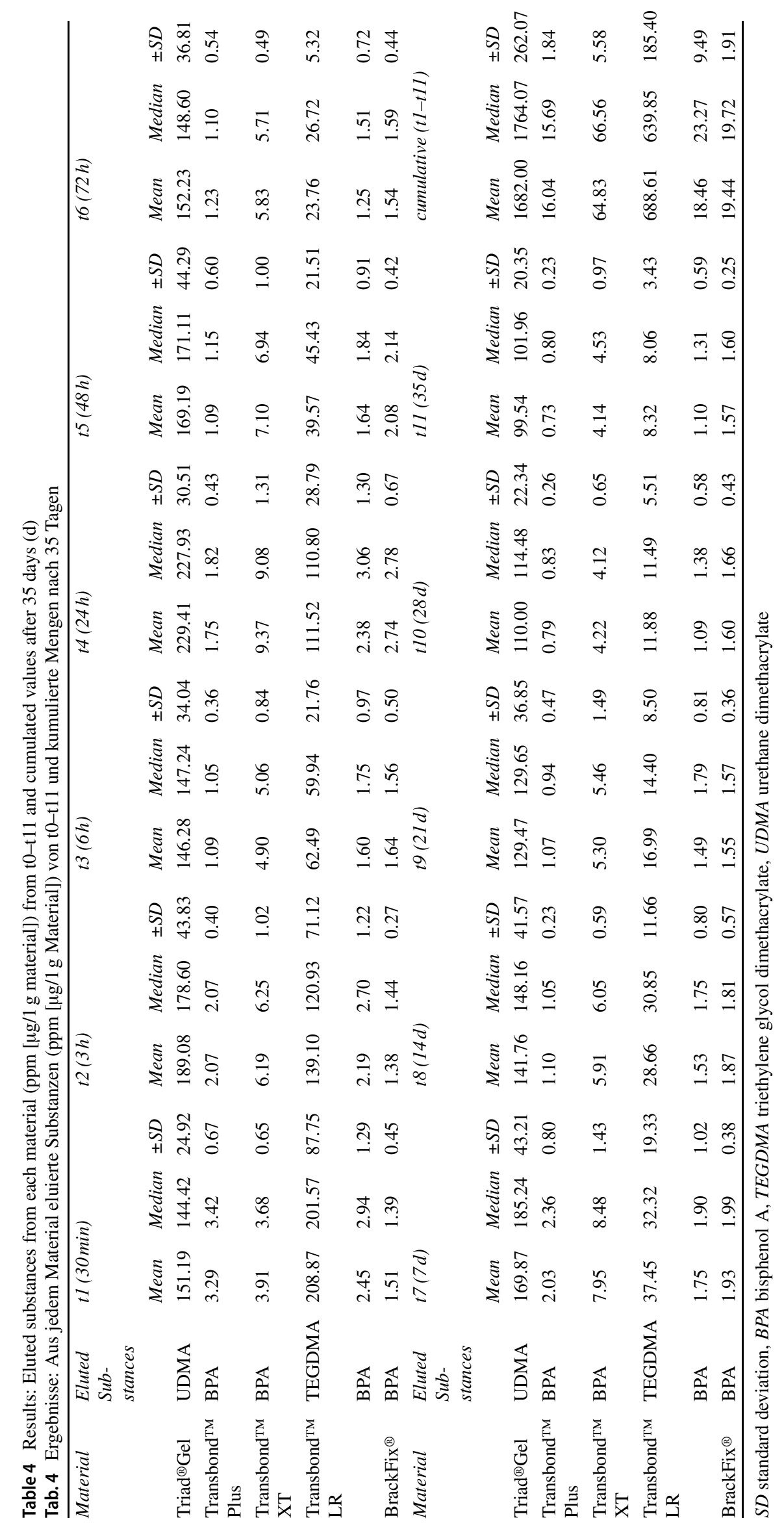




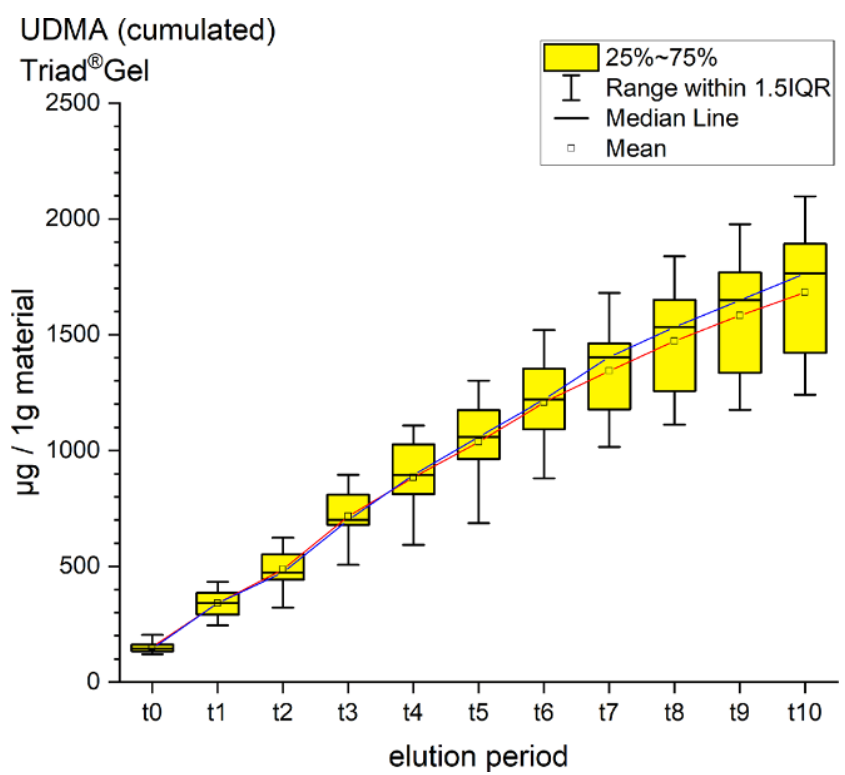

Fig. 2 Cumulated quantity of eluted urethane dimethacrylate (UDMA $[\mu \mathrm{g}])$ from $1 \mathrm{~g}$ Triad ${ }^{\circledR} \mathrm{Gel}$. The red line indicates the progression of the mean values; the blue line of the median values of each measurement point from t0-t11. IQR interquartile range

Abb. 2 Kumulierte Menge von eluiertem UDMA (Urethan-Dimethacrylat $[\mu \mathrm{g}])$ aus $1 \mathrm{~g}$ Triad ${ }^{\circledR} \mathrm{Gel}$. Die rote Kurve stellt die Entwicklung der errechneten Mittelwerte dar, die blaue Kurve die der Mediane über den Untersuchungszeitraum (t0-t11). IQR Interquartilbereich

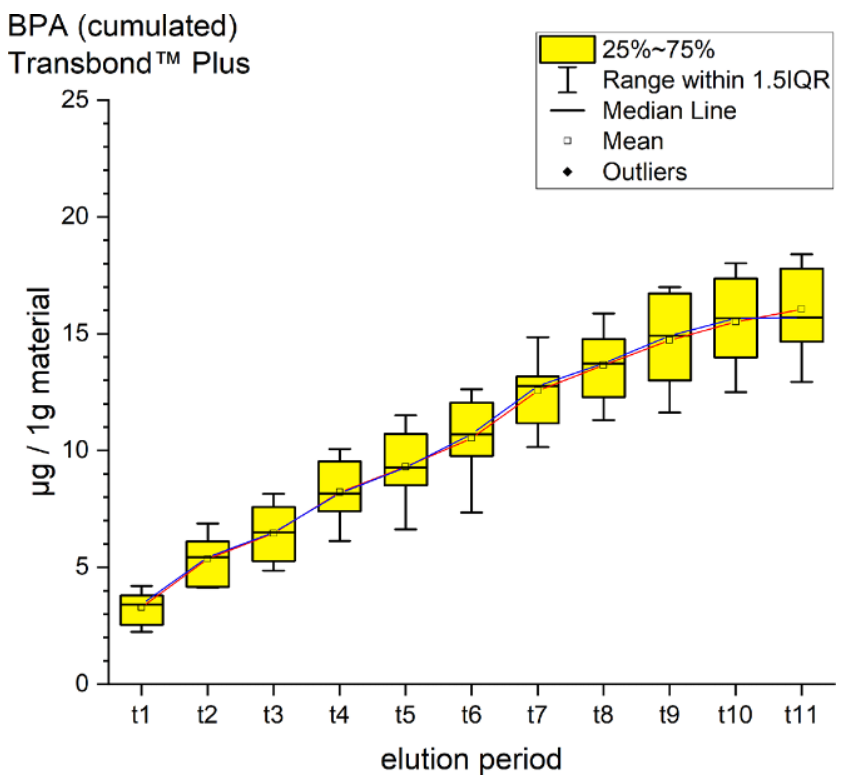

Fig. 3 Cumulated quantity of eluted bisphenol A (BPA; $[\mu \mathrm{g}])$ from $1 \mathrm{~g}$ Transbond ${ }^{\mathrm{TM}}$ Plus. The red line indicates the progression of the mean values from $\mathrm{t} 0-\mathrm{t} 11$; the blue line of the median. IQR interquartile range Abb. 3 Kumulierte Menge von eluiertem BPA (Bisphenol A; $[\mu \mathrm{g}]$ ) aus $1 \mathrm{~g}$ Transbond ${ }^{\mathrm{TM}}$ Plus. Die rote Kurve stellt die Entwicklung der errechneten Mittelwerte über den Untersuchungszeitraum (t0-t11) dar, die blaue Kurve die der Mediane. IQR Interquartilbereich

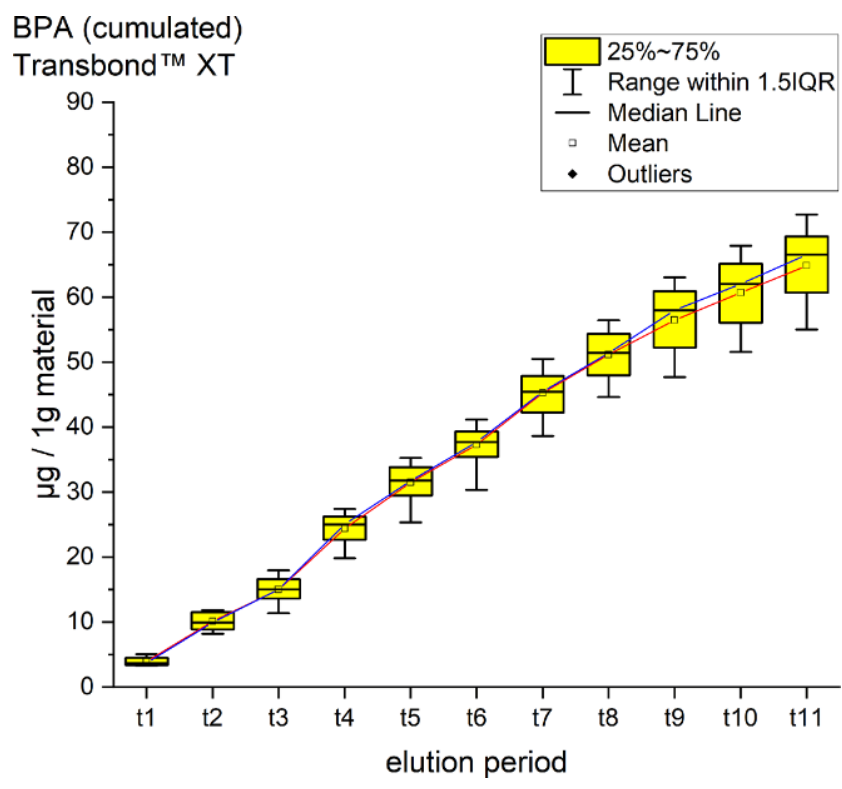

Fig. 4 Cumulated quantity of eluted bisphenol A (BPA; $[\mu \mathrm{g}])$ from $1 \mathrm{~g}$ Transbond ${ }^{\mathrm{TM}} \mathrm{XT}$. The red line indicates the progression of the mean values from $\mathrm{t} 0-\mathrm{t} 11$; the blue line of the median. IQR interquartile range Abb. 4 Kumulierte Menge von eluiertem BPA [ $\mu \mathrm{g}]$ aus $1 \mathrm{~g}$ Transbond $^{\mathrm{TM}}$ XT. Die rote Kurve stellt die Entwicklung der errechneten Mittelwerte über den Untersuchungszeitraum ( $\mathrm{t} 0-\mathrm{t} 11)$ dar, die blaue Kurve die der Mediane. IQR Interquartilbereich

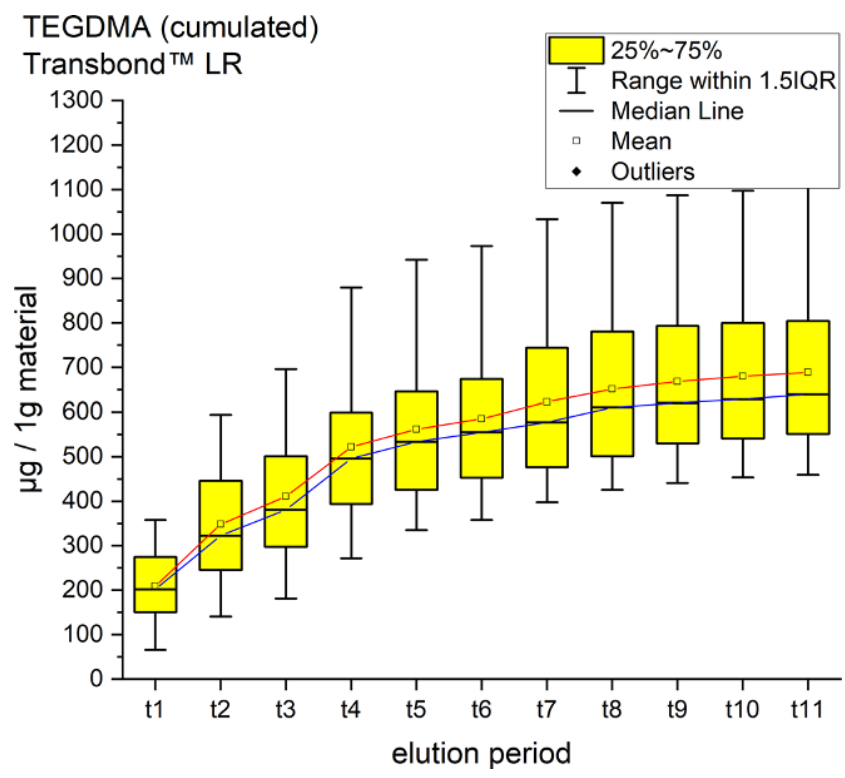

Fig. 5 Cumulated quantity of eluted triethylene glycol dimethacrylate (TEGDMA; $[\mu \mathrm{g}])$ from $1 \mathrm{~g}$ Transbond ${ }^{\mathrm{TM}} \mathrm{LR}$. The red line indicates the progression of the mean values from $\mathrm{t} 0-\mathrm{t} 11$; the blue line of the median. IQR interquartile range

Abb. 5 Kumulierte Menge von eluiertem TEGDMA (Triethylenglykol-Dimethacrylat; $[\mu \mathrm{g}])$ aus $1 \mathrm{~g}$ Transbond ${ }^{\mathrm{TM}} \mathrm{LR}$. Die rote Kurve stellt die Entwicklung der errechneten Mittelwerte über den Untersuchungszeitraum (t0-t11) dar, die blaue Kurve die der Mediane. IQR Interquartilbereich 


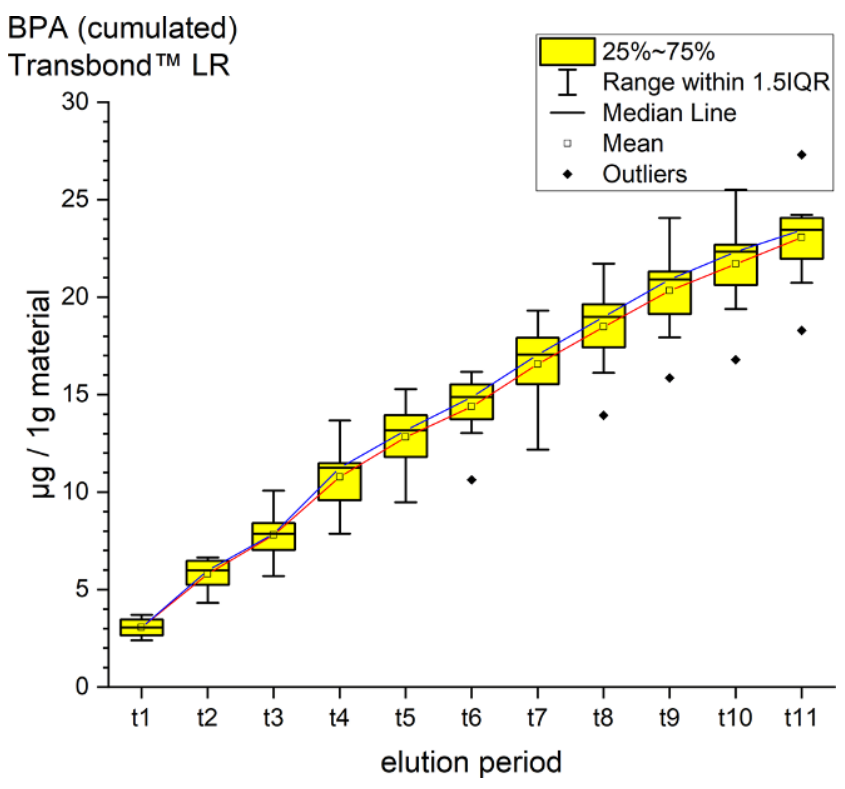

Fig. 6 Cumulated quantity of eluted bisphenol A (BPA; $[\mu \mathrm{g}])$ from $1 \mathrm{~g}$ Transbond ${ }^{\mathrm{TM}} \mathrm{LR}$. The red line represents the progression of the mean values from $\mathrm{t} 0-\mathrm{t} 11$, the blue line of the median. IQR interquartile range Abb. 6 Kumulierte Menge von eluiertem BPA (Bisphenol A; $[\mu \mathrm{g}])$ aus $1 \mathrm{~g}$ Transbond ${ }^{\mathrm{TM}}$ LR. Die rote Kurve stellt die Entwicklung der errechneten Mittelwerte über den Untersuchungszeitraum (t0-t11) dar, die blaue Kurve die der Mediane. IQR Interquartilbereich

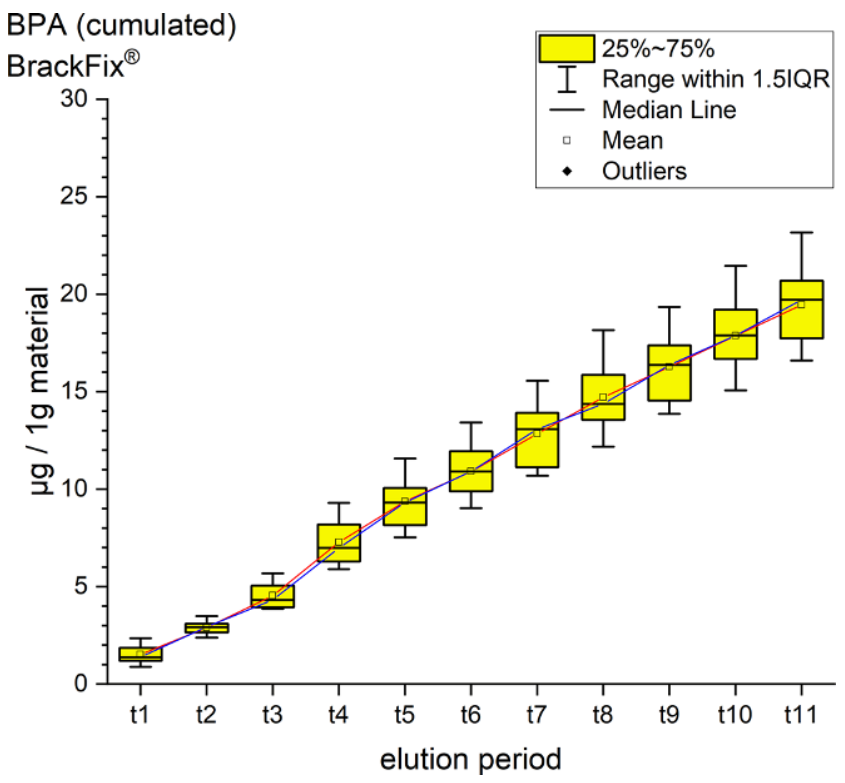

Fig. 7 Cumulated quantity of eluted bisphenol A (BPA; $[\mu \mathrm{g}])$ from $1 \mathrm{~g}$ BrackFix ${ }^{\circledR}$. The red line represents the progression of the mean values from $\mathrm{t} 0-\mathrm{t} 11$, the blue line of the median. IQR interquartile range

Abb. 7 Kumulierte Menge von eluiertem BPA (Bisphenol A; $[\mu \mathrm{g}]$ ) aus $1 \mathrm{~g} \mathrm{BrackFix}{ }^{\circledR}$. Die rote Kurve stellt die Entwicklung der errechneten Mittelwerte über den Untersuchungszeitraum ( $\mathrm{t} 0-\mathrm{t} 11)$ dar, die blaue Kurve die der Mediane. IQR Interquartilbereich
For BPA the time-dependent curves (Fig. 8) of the four materials were different (interaction $p$ value from 2-way ANOVA $<0.001)$. Where Transbond ${ }^{\mathrm{TM}}$ Plus, Transbond ${ }^{\mathrm{TM}}$ LR and BrackFix ${ }^{\circledR}$ showed very similar low elusion rates (maximum cumulated mean elusion after 35 days (t11) from $14.44 \mathrm{ppm}$ to $19.44 \mathrm{ppm}$, see above), Transbond ${ }^{\mathrm{TM}}$ XT showed a substantially higher elusion $(64.83 \mathrm{ppm})$. The cumulated elution of BPA from Transbond ${ }^{\mathrm{TM}}$ XT after 35 days (t11) was approximately four times higher than from the other three materials.

\section{Discussion}

This HPLC study identified and quantified the release of three monomers (BPA, UDMA and TEGDMA) from five different orthodontic materials $\left(\right.$ BrackFix $^{\circledR}$, $\operatorname{Triad}^{\circledR} \mathrm{Gel}$, Transbond $^{\mathrm{TM}}$ XT, Transbond ${ }^{\mathrm{TM}}$ LR, Transbond ${ }^{\mathrm{TM}}$ Plus) eluted in artificial saliva over 5 weeks.

Various substances listed in the safety data sheets (SDS) and also not uniquely identified or not mentioned eluted substances have been detected. Every identified substance, besides BPA leaching from Transbond ${ }^{\mathrm{TM}}$ Plus, is listed in the SDS of the tested materials. The eluted and detected BPA, (or possible BPA derivatives as persecutors of bisGMA and bis-EMA), is possibly a degradation product of larger substances, or its match in composition is too small to be mentioned in the SDS [27, 30]. Other studies also found substances not mentioned in the SDS [1]. Monomers of smaller molecular weight, such as TEGDMA or BPA are more likely and faster to leach from dental materials than monomers of higher molecular weight (e.g., bis-GMA, Figs. 8, 9 and 10; [52]). In addition, smaller peaks below the threshold with the same retention time as bis-GMA appeared in the chromatograms of Transbond ${ }^{\mathrm{TM}}$ Plus and BrackFix ${ }^{\circledR}$ aliquots.

Other substances were released but could not be identified. The identity of those can be assumed by comparing their characteristics in the chromatograms with other monomers used in the analyzed standards. For Transbond ${ }^{\mathrm{TM}}$ Plus, besides low concentrations of BPA, two unidentified peaks can be seen. The characteristics of the peaks do show a similar, but not the exact and constant retention time as hydroquinone (HQ) and camphorquinone (CQ) used in the standards. Furthermore, the spectrum of the peaks differs as well to HQ and CQ. The additional substances (HQ and CQ) and others in the standards are often found in orthodontic and dental resins. They are for example used as photoinitiators, inhibitors and stabilizers or as residues of the raw materials. Even if not mentioned in the SDS, especially gas chromatography/mass spectrometry (GC/MS) studies have shown a release of CQ $[1,39,50]$. The SDS of Transbond ${ }^{\mathrm{TM}}$ Plus gives information about two substances 
Fig. 8 Comparison of the cumulated quantities of eluted bisphenol A (BPA, $[\mu \mathrm{g}])$ from $1 \mathrm{~g}$ Transbond ${ }^{\mathrm{TM}}$ Plus, Transbond $^{\mathrm{TM}}$ XT, Transbond ${ }^{\mathrm{TM}} \mathrm{LR}$, BrackFix ${ }^{\circledR}$ over 35 days

Abb. 8 Gegenüberstellung der kumulierten Mengen von eluieraus $1 \mathrm{~g}$ Transbond ${ }^{\mathrm{TM}}$ Plus, Transbond $^{\mathrm{TM}}$ XT, Transbond ${ }^{\mathrm{TM}} \mathrm{LR}$, BrackFix ${ }^{\circledR}$ im zeitlichen Verlauf über 35 Tage tem BPA (Bisphenol A; $[\mu \mathrm{g}]$ )

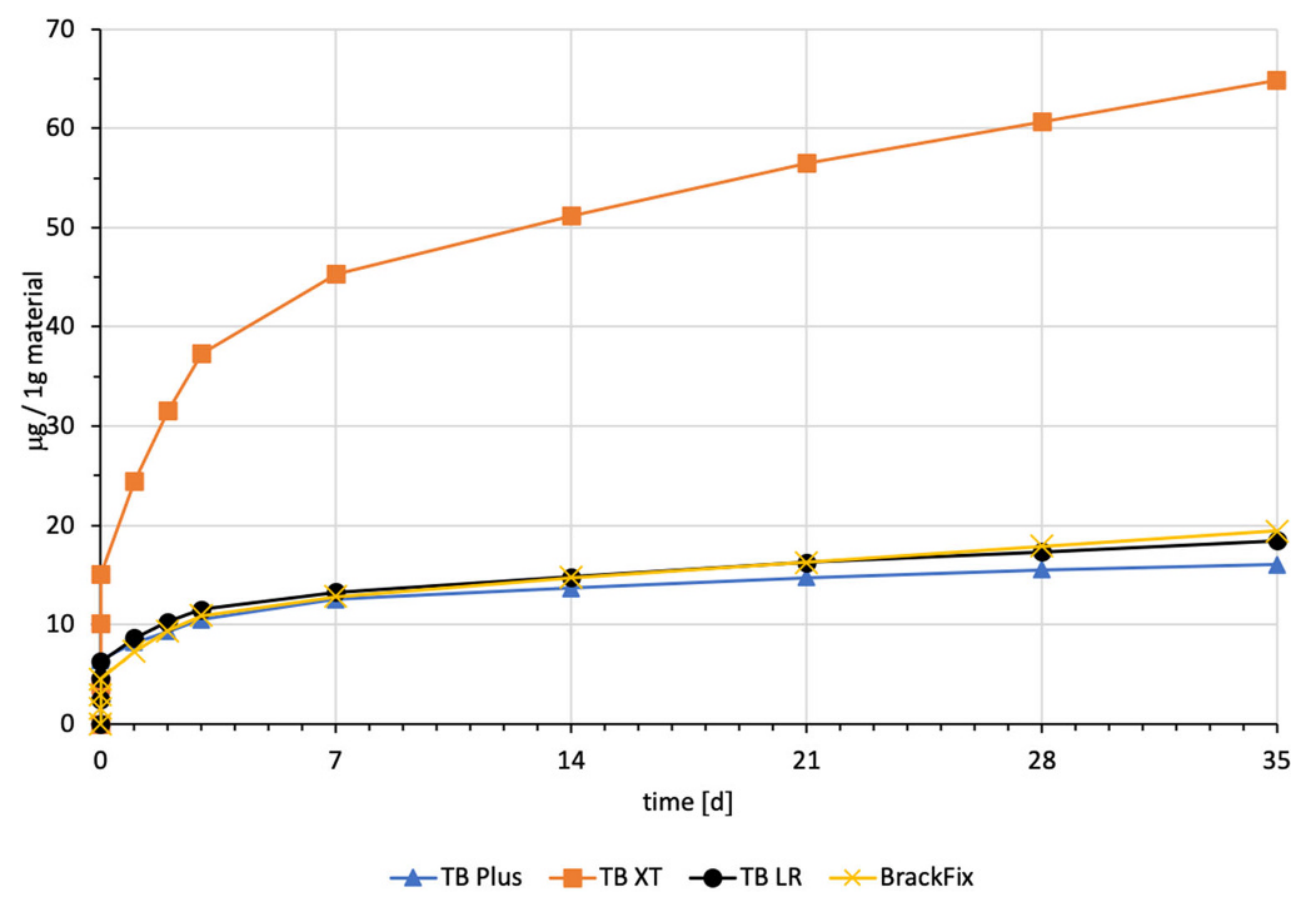

Fig. 9 Cumulated quantity (mean) of eluted urethane dimethacrylate (UDMA; $[\mu \mathrm{g}]$ ) from $1 \mathrm{~g}$ Triad ${ }^{\circledR} \mathrm{Gel}$ over 35 days (d)

Abb. 9 Kumulierte Mengen (Mittelwerte) von eluiertem UDMA (Urethan-Dimethacrylat; [ $\mu \mathrm{g}])$ aus $1 \mathrm{~g}$ Triad ${ }^{\circledR} \mathrm{Gel}$ im zeitlichen Verlauf über 35 Tage

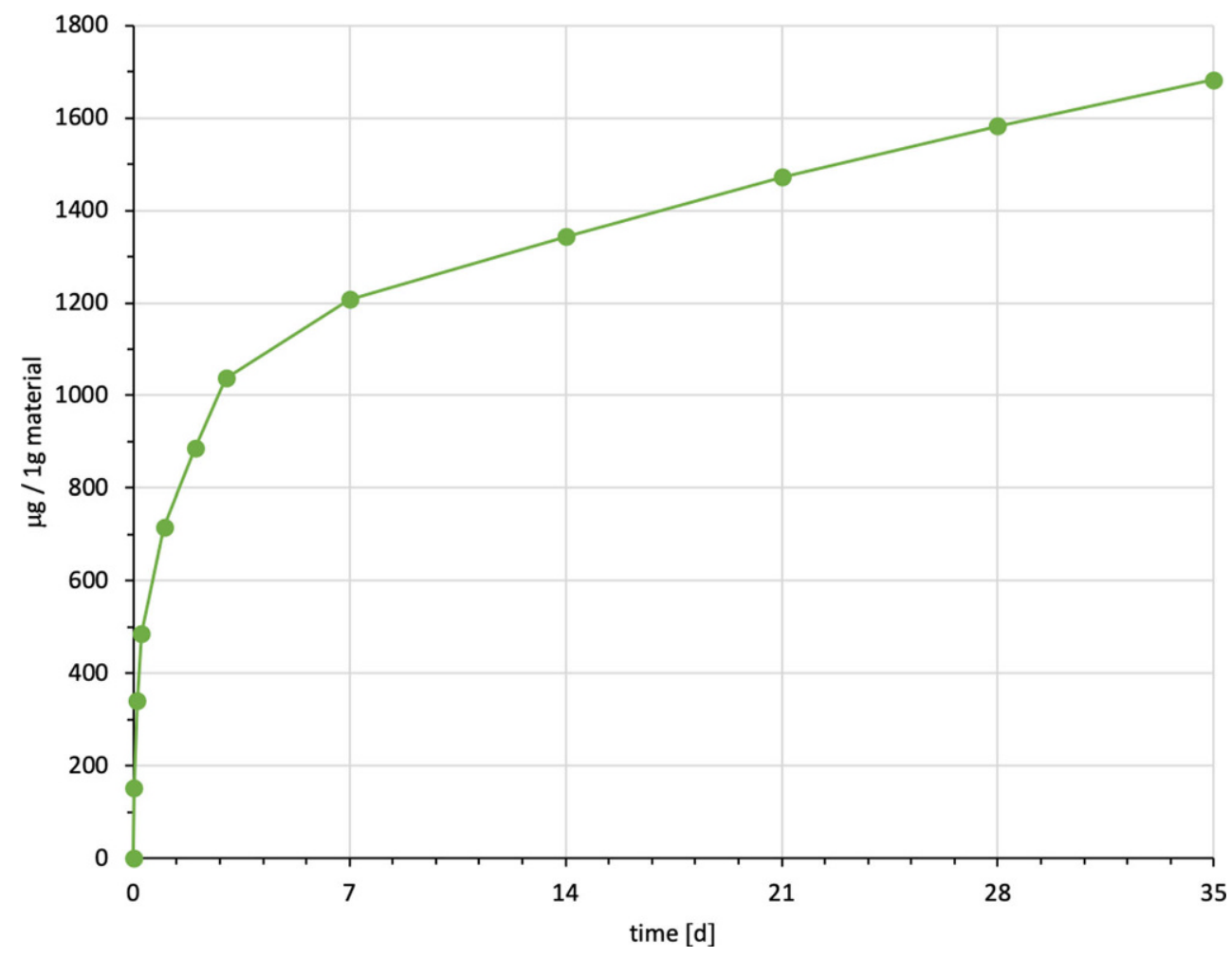

(glycerol 1,3-dimethacrylate, diphenyliodonium hexafluorophosphate) not used in the standard. The two substances are suspected of causing the unidentified peaks in the chromatograms of Transbond ${ }^{\mathrm{TM}}$ Plus aliquots.

Comparing the materials and the measured amounts of the identified substances to each other, Triad ${ }^{\circledR}$ Gel eluted the most with a mean of 1682 ppm of UDMA after 35 days.
Followed by Transbond ${ }^{\mathrm{TM}}$ LR with a cumulative mean of $688.61 \mathrm{ppm}$ TEGDMA. For both substances, there are no limits published for a maximum daily intake by authorities.

BPA was found to eluate from four materials. The highest cumulative mean showed Transbond ${ }^{\mathrm{TM}}$ XT (64.83 ppm) after 35 days, followed by BrackFix ${ }^{\circledR}$ (19.44 ppm), Transbond $^{\mathrm{TM}}$ LR (18.46 ppm) and Transbond ${ }^{\mathrm{TM}}$ Plus (14.44 ppm). 
Focusing on the elution process of BPA over time, three materials (Transbond ${ }^{\mathrm{TM}}$ LR, Transbond ${ }^{\mathrm{TM}}$ Plus, BrackFix ${ }^{\circledR}$ ) showed similar characteristics in the graph. Only Transbond $^{\mathrm{TM}} \mathrm{XT}$ showed a major deviation compared to the others with higher concentrations and an extended elution process (Fig. 8). The already mentioned degradation process of larger molecular structures with time, different compositions of the materials or the unlikely case of another unknown substance with similar characteristics in the HPLC chromatogram leading to a larger peak with the retention time of BPA could explain this observation.

When it comes to the range of indications of the materials, both Transbond ${ }^{\mathrm{TM}} \mathrm{XT}$ and BrackFix ${ }^{\circledR}$ are used for bracket bonding. Based on the results of our study BrackFix ${ }^{\circledR}$ should be preferred, provided that other material characteristics like sufficient tensile and shear strength are similar.

Comparing the results with other studies, it is important to point out the different approaches, which make comparisons difficult. The elution of material samples in artificial saliva at $+37^{\circ} \mathrm{C}$ aims at simulating intraoral conditions. However, the experimental setup still does not include possible impacts of bacterial and salivary enzymes in the human oral flora, $\mathrm{pH}$ and thermal changes [30]. Kloukos et al. [26] compared other studies in the field of interest, with the result that most authors used different methods. Different analyzing methods like liquid chromatography coupled with mass spectrometry (LC/MS) or gas chromatography (GC) coupled with MS show major differences in the results of the studies. Different elution media, such as water, ethanol or combinations are common. Ethanol is known to accelerate the aging of polymers [10], but it is questionable whether ethanol creates a comparable aging process as if the materials are immersed in saliva. Regarding the period of elution, we tried to create realistic conditions by expanding our study to a time period of 5 weeks to extend the test period. The size, surface and weight of the specimens in perspective with the immersion medium and the time of elution are also factors that have to be taken into consideration when comparing different studies. In vivo, microfractures at the peripheral margins of orthodontic brackets and bands or within adhesives and a lower degree of conversion of the resins under brackets and bands could be another source of higher leakage of monomers. On the other side, the exposed surface of the resins to the oral cavity is most likely smaller than in our study, since resins for bracket bonding (BrackFix ${ }^{\circledR}$, Trandbond ${ }^{\mathrm{TM}} \mathrm{XT}$ ) or cementing bands (Transbond ${ }^{\mathrm{TM}}$ Plus) are mostly covered by enamel, bands or bracket bases [10]. According to a review by Van Landuyt et al. the release of monomers depends on the exposed surface of samples, but there is no significant correlation with the volume [53].
Thus, it is difficult to determine the actual time of exposure, quantity, volume and surface area of the different materials used in vivo. Different numbers of teeth per patient, various appliances, the modification of these, the process of band or bracket bonding, re- and debonding or the removal of excess material are just a few potential variables. It is reasonable to conclude that the tested amount of the different materials in this study are far lower than the actual amount emerging during orthodontic treatment.

In general, we confirm the statement of most HPLC studies testing Transbond ${ }^{\mathrm{TM}}$ XT leakage of BPA $[43,51]$. Only Malkiewicz et al. diverged from our study stating that there is no release of BPA from Transbond ${ }^{\mathrm{TM}} \mathrm{XT}$ [30]. GC/MS studies support overall the results with the elution of BPA from Transbond ${ }^{\mathrm{TM}}$ XT $[11,27]$. In addition, Transbond ${ }^{\mathrm{TM}}$ LR also eluted TEGDMA in our setup which is the first HPLC study showing that effect [39].

The applied method is an in vitro model attempting to replicate oral conditions based on the recommendations for a standardization by Kloukos et al. [26]. In combination with HPLC, this is a valid and simple method to identify and quantify different monomers released from orthodontic resins [51]. However, HPLC coupled with a mass spectrometry (MS) or a pre-analytical purification of aliquots might have identified further substances [31, 42]. However, adding more substances to the standards also expands the possibility to identify additional substances with the existing method. We analyzed new and previously tested materials with this method and compared our results with other studies [26].

Deviations in the appearance of the peaks in the chromatograms were found, resulting in variances of the area under the curve values and the relating calculated concentration of leached monomers in the aliquots. These anomalies might be the result of a pollution of the HPLC columns after several analytical runs, leading to split peaks, peak covering, fronting, broadening or tailing [58].

Possible disturbing factors which lead to the pollution of the columns are different ingredients of the artificial saliva like salts, unintentionally added smaller particles from the used materials or laboratory devices in the aliquots or debris from HPLC tubes. Major improvements in the appearance of the peaks in the chromatogram, such as less fronting or tailing and less split peaks or other signs for column pollution were achieved by the replacement of pre- and main columns during our research. In this study, the precolumns have been replaced three times, the main column once. For perfect conditions, the HPLC columns should be replaced, calibrated with standards and the system rinsed and purged regularly. Aliquots can be purified for even better conditions.

Additional disturbing factors which may lead to a wider spread of the results should be discussed and eliminated. 
Fig. 10 Cumulated quantity (mean) of eluted triethylene glycol dimethacrylate (TEGDMA; $[\mu \mathrm{g}])$ from $1 \mathrm{~g}$ Transbond ${ }^{\mathrm{TM}} \mathrm{LR}$ over 35 days $(\mathrm{d})$

Abb. 10 Kumulierte Mengen (Mittelwerte) von eluiertem TEGDMA (TriethylenglykolDimethacrylat; $[\mu \mathrm{g}])$ aus $1 \mathrm{~g}$ Transbond ${ }^{\mathrm{TM}}$ LR im zeitlichen Verlauf über 35 Tage

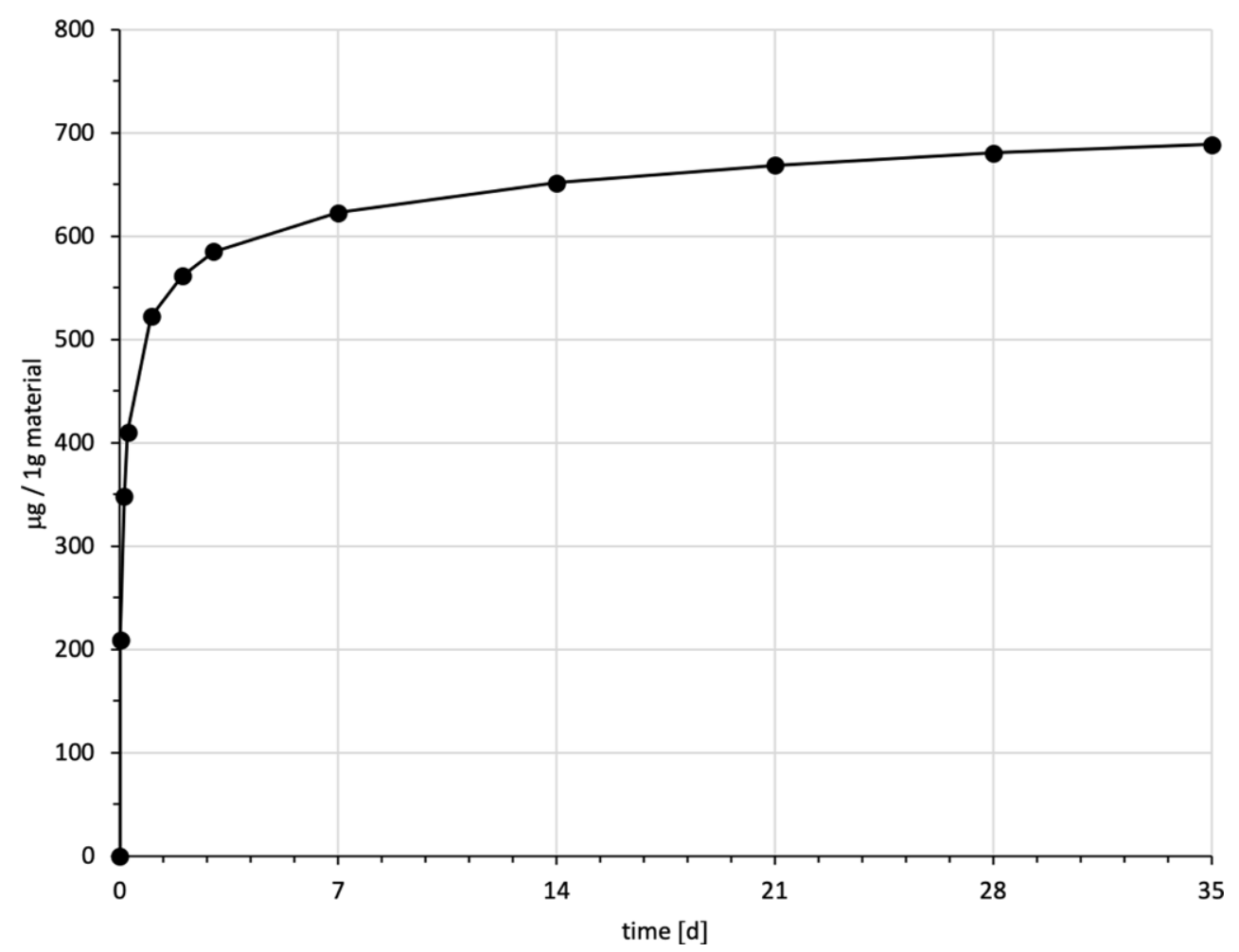

For example, to prevent thermal changes, placing the HPLC in a room with a constant room temperature is recommended. In addition, reactions between the substances in the aliquots, due to ambient light or a different degree of conversation in the polymerization step as a result of differences in the curing light system, distance and time are possible [51].

To minimize sources of error, we standardized the process inter alia by using just one fully charged light-emitting diode device (LED) for every material, which is common in daily dental work and superior to a halogen light-curing unit [43]. Custom-made polymerization stands to keep the same distance were used. The experiments were performed in a laboratory protected from direct UV light. The time between pipetting aliquots and HPLC run was held constant throughout the study.

Regarding the medical point of view and potential health threats, the in vitro detected concentrations of BPA from the different materials in the aliquots of artificial saliva remained all below the threshold of $4 \mu \mathrm{g} / \mathrm{kg}$ body weight/day set by the EFSA in 2015 [8].

As a general premise it is important to minimize the exposure to any monomers. Any sources like food, packaging, daily polymers, paints, coatings, electric components and especially medical devices and appliances should be seen as part of the bigger picture [27]. Another reason for a potential higher exposure to monomers while undergoing orthodontic treatment is that volatile substances are not measured by this method. Possibilities of systematic intake other than through the oral environment include the respiratory and gastrointestinal tract or by physical contact [21]. Several in vitro and in vivo studies confirm our results that the concentrations of the eluted substance BPA are highest right after placement in the oral cavity or during the initial elution period $[15,37,39]$. In our study, every material and eluted substance showed the same effect: the highest concentrations were measured in the first period after bonding and the amount of eluted substances decreased with time (Figs. 8, 9 and 10). Thus, according to the eluted concentrations, a crucial period of time are the first $6 \mathrm{~h}(\mathrm{t} 0-\mathrm{t} 3)$ for substances with a low-molecular weight (BPA and TEGDMA, Figs. 8 and 10$)$ and $72 \mathrm{~h}(\mathrm{t} 0-\mathrm{t} 6)$ for substances with a highmolecular weight (UDMA, Fig. 9). The lowest concentrations for every material were measured in the last period (t11). These characteristics are of major importance for the management of exposure during and right after the bonding and debonding process.

Teenagers are the major recipients of orthodontic treatment. This age is characterized by growth with several hormonal changes where endocrine-active substances like BPA might have an impact on development [27].

On the other hand, long-term effects for dental professionals should also be closely monitored to reduce potential harmful effects to their health. Further attempts to reduce monomer leakage and exposure to patients and dental professionals should be made. Common recommendations suggest dental dams while bonding, which is not practicable or can only be performed at disproportionate expense. Another 
suggestion is removing any excess adhesive before curing, generally to minimize the amount of material. The distance from material to the light-cure tip should be minimized to reach the highest degree of conversion as possible. The use of spray water and rinsing of the patients' oral cavity multiple times with warm water after bonding and debonding is advisable. Also, suction devices should always be used to minimize aerosol while bonding and debonding. The use of alternative materials not containing any leaking monomers linked to health hazards, equipment for self-protection such as glasses, gloves and face masks are indicated [9, 26, 27].

In addition to existing regulations and recommendations, thresholds for other substances such as TEGDMA and UDMA should be considered by authorities. The impact of cumulative or low-dose effects over a long period should not be underestimated and should be taken into consideration $[55,56]$. This will be of benefit for health providers, patients and the environment exposed to monomers.

Funding Open Access funding enabled and organized by Projekt DEAL.

\section{Declarations}

Conflict of interest B. J. Kux, L. M. Bacigalupo, A. Scriba, M. Emmrich and P.-G. Jost-Brinkmann declare that they have no competing interests.

Ethical standards For this article no studies with human participants or animals were performed by any of the authors. All studies performed were in accordance with the ethical standards indicated in each case.

Open Access This article is licensed under a Creative Commons Attribution 4.0 International License, which permits use, sharing, adaptation, distribution and reproduction in any medium or format, as long as you give appropriate credit to the original author(s) and the source, provide a link to the Creative Commons licence, and indicate if changes were made. The images or other third party material in this article are included in the article's Creative Commons licence, unless indicated otherwise in a credit line to the material. If material is not included in the article's Creative Commons licence and your intended use is not permitted by statutory regulation or exceeds the permitted use, you will need to obtain permission directly from the copyright holder. To view a copy of this licence, visit http://creativecommons.org/licenses/by/4. $0 /$.

\section{References}

1. Bationo R, Jordana F, Boileau MJ, Colat-Parros J (2016) Release of monomers from orthodontic adhesives. Am J Orthod Dentofacial Orthop 150:491-498. https://doi.org/10.1016/j.ajodo.2016.02.027

2. Bowen RL (1963) Properties of a silica-reinforced polymer for dental restorations. J Am Dent Assoc 66:57-64

3. Calafat AM, Ye X, Wong LY, Reidy JA, Needham LL (2008) Exposure of the U.S. population to bisphenol A and 4-tertiary-octylphenol: 2003-2004. Environ Health Perspect 116:39-44. https://doi. org/10.1289/ehp.10753

4. Chen D, Kannan K, Tan H, Zheng Z, Feng YL, Wu Y, Widelka M (2016) Bisphenol Analogues Other Than BPA: Environmental Oc- currence, Human Exposure, and Toxicity-A Review. Environ Sci Technol 50:5438-5453. https://doi.org/10.1021/acs.est.5b05387

5. Chung KH, Greener EH (1990) Correlation between degree of conversion, filler concentration and mechanical properties of posterior composite resins. J Oral Rehabil 17:487-494

6. Cwiek-Ludwicka K (2015) Bisphenol A (BPA) in food contact materials-new scientific opinion from EFSA regarding public health risk. Rocz Panstw Zakl Hig 66:299-307

7. Durner J, Wellner P, Hickel R, Reichl FX (2012) Synergistic interaction caused to human gingival fibroblasts from dental monomers. Dent Mater 28:818-823. https://doi.org/10.1016/j.dental.2012.04. 031

8. EFSA (2017) Bisphenol A. (European Food Safety Authority). https://www.efsa.europa.eu/en/topics/topic/bisphenol. Accessed 19 Feb 2019

9. Eliades T (2017) Bisphenol A and orthodontics: An update of evidence-based measures to minimize exposure for the orthodontic team and patients. Am J Orthod Dentofacial Orthop 152:435-441. https://doi.org/10.1016/j.ajodo.2017.08.004

10. Eliades T, Hiskia A, Eliades G, Athanasiou AE (2007) Assessment of bisphenol-A release from orthodontic adhesives. Am J Orthod Dentofacial Orthop 131:72-75. https://doi.org/10.1016/j. ajodo.2006.08.013

11. Eliades T, Voutsa D, Sifakakis I, Makou M, Katsaros C (2011) Release of bisphenol-A from a light-cured adhesive bonded to lingual fixed retainers. Am J Orthod Dentofacial Orthop 139:192-195. https://doi.org/10.1016/j.ajodo.2009.12.026

12. Emmler J, Seiss M, Kreppel H, Reichl FX, Hickel R, Kehe K (2008) Cytotoxicity of the dental composite component TEGDMA and selected metabolic by-products in human pulmonary cells. Dent Mater 24:1670-1675. https://doi.org/10.1016/j.dental.2008.04.001

13. FDA (2018) Bisphenol A (BPA): use in food contact application. American Food and Drug Administration. http://www.fda.gov/ newsevents/publichealthfocus/ucm064437.htm\#current. . Accessed Feb. 192019

14. Ferreira LL, Couto R, Oliveira PJ (2015) Bisphenol A as epigenetic modulator: setting the stage for carcinogenesis? Eur J Clin Invest 45 Suppl 1:32-36. https://doi.org/10.1111/eci.12362

15. Fung EY, Ewoldsen NO, St Germain HA, Jr., Marx DB, Miaw CL, Siew C, Chou HN, Gruninger SE, Meyer DM (2000) Pharmacokinetics of bisphenol A released from a dental sealant. J Am Dent Assoc 131:51-58. https://doi.org/10.14219/jada.archive.2000.0019

16. Geurtsen W, Leyhausen G (2001) Chemical-Biological Interactions of the resin monomer triethyleneglycol-dimethacrylate (TEGDMA). J Dent Res 80:2046-2050. https://doi.org/10.1177/ 00220345010800120401

17. Goldberg M (2008) In vitro and in vivo studies on the toxicity of dental resin components: a review. Clin Oral Investig 12:1-8. https://doi.org/10.1007/s00784-007-0162-8

18. Goon AT, Isaksson M, Zimerson E, Goh CL, Bruze M (2006) Contact allergy to (meth)acrylates in the dental series in southern Sweden: simultaneous positive patch test reaction patterns and possible screening allergens. Contact Derm 55:219-226. https://doi.org/10. 1111/j.1600-0536.2006.00922.x

19. Gosavi SS, Gosavi SY, Alla RK (2010) Local and systemic effects of unpolymerised monomers. Dent Res J (isfahan) 7:82-87

20. Gupta SK, Saxena P, Pant VA, Pant AB (2012) Release and toxicity of dental resin composite. Toxicol Int 19:225-234. https://doi.org/ 10.4103/0971-6580.103652

21. Hahladakis JN, Velis CA, Weber R, Iacovidou E, Purnell P (2018) An overview of chemical additives present in plastics: Migration, release, fate and environmental impact during their use, disposal and recycling. J Hazard Mater 344:179-199. https://doi.org/10. 1016/j.jhazmat.2017.10.014

22. Hervas-Garcia A, Martinez-Lozano MA, Cabanes-Vila J, BarjauEscribano A, Fos-Galve P (2006) Composite resins. A review of the 
materials and clinical indications. Med Oral Patol Oral Cir Bucal 11:E215-220

23. Howe SR, Borodinsky L (1998) Potential exposure to bisphenol A from food-contact use of polycarbonate resins. Food Addit Contam 15:370-375. https://doi.org/10.1080/02652039809374653

24. Jedeon K, Loiodice S, Marciano C, Vinel A, Canivenc Lavier MC, Berdal A, Babajko S (2014) Estrogen and bisphenol A affect male rat enamel formation and promote ameloblast proliferation. Endocrinology 155:3365-3375. https://doi.org/10.1210/en.20132161

25. Kleinsasser NH, Schmid K, Sassen AW, Harreus UA, Staudenmaier R, Folwaczny M, Glas J, Reichl FX (2006) Cytotoxic and genotoxic effects of resin monomers in human salivary gland tissue and lymphocytes as assessed by the single cell microgel electrophoresis (Comet) assay. Biomaterials 27:1762-1770. https://doi. org/10.1016/j.biomaterials.2005.09.023

26. Kloukos D, Pandis N, Eliades T (2013) Bisphenol-A and residual monomer leaching from orthodontic adhesive resins and polycarbonate brackets: a systematic review. Am J Orthod Dentofacial Orthop 143:S104-112

27. Kotyk MW, Wiltshire WA (2014) An investigation into bisphenol-A leaching from orthodontic materials. Angle Orthod 84:516-520. https://doi.org/10.2319/081413-600.1

28. Lindstrom M, Alanko K, Keskinen H, Kanerva L (2002) Dentist's occupational asthma, rhinoconjunctivitis, and allergic contact dermatitis from methacrylates. Allergy 57:543-545

29. Liu X, Miao M, Zhou Z, Gao E, Chen J, Wang J, Sun F, Yuan W, Li DK (2015) Exposure to bisphenol-A and reproductive hormones among male adults. Environ Toxicol Pharmacol 39:934-941. https://doi.org/10.1016/j.etap.2015.03.007

30. Malkiewicz K, Turlo J, Marciniuk-Kluska A, Grzech-Lesniak K, Gasior M, Kluska M (2015) Release of bisphenol A and its derivatives from orthodontic adhesive systems available on the European market as a potential health risk factor. Ann Agric Environ Med 22:172-177. https://doi.org/10.5604/12321966.1141390

31. Manoj MK, Ramakrishnan R, Babjee S, Nasim R (2018) High-performance liquid chromatography analysis of salivary bisphenol $\mathrm{A}$ levels from light-cured and chemically cured orthodontic adhesives. Am J Orthod Dentofacial Orthop 154:803-808. https://doi.org/10. 1016/j.ajodo.2018.02.008

32. Maserejian NN, Shrader P, Trachtenberg FL, Hauser R, Bellinger DC, Tavares M (2014) Dental sealants and flowable composite restorations and psychosocial, neuropsychological, and physical development in children. Pediatr Dent 36:68-75

33. Maserejian NN, Trachtenberg FL, Hauser R, McKinlay S, Shrader P, Tavares M, Bellinger DC (2012) Dental composite restorations and psychosocial function in children. Pediatrics 130:e328-338. https:// doi.org/10.1542/peds.2011-3374

34. Michalowicz J (2014) Bisphenol A—sources, toxicity and biotransformation. Environ Toxicol Pharmacol 37:738-758. https://doi.org/ 10.1016/j.etap.2014.02.003

35. Mielke H, Gundert-Remy U (2009) Bisphenol A levels in blood depend on age and exposure. Toxicol Lett 190:32-40. https://doi. org/10.1016/j.toxlet.2009.06.861

36. Minguez N, Ellacuria J, Soler JI, Triana R, Ibaseta G (2003) Advances in the history of composite resins. J Hist Dent 51:103-105

37. Moreira MR, Matos LG, de Souza ID, Brigante TA, Queiroz ME, Romano FL, Nelson-Filho P, Matsumoto MA (2017) Bisphenol A release from orthodontic adhesives measured in vitro and in vivo with gas chromatography. Am J Orthod Dentofacial Orthop 151:477-483. https://doi.org/10.1016/j.ajodo.2016.07.019

38. Nah WH, Park MJ, Gye MC (2011) Effects of early prepubertal exposure to bisphenol A on the onset of puberty, ovarian weights, and estrous cycle in female mice. Clin Exp Reprod Med 38:75-81. https://doi.org/10.5653/cerm.2011.38.2.75
39. Pelourde C, Bationo R, Boileau MJ, Colat-Parros J, Jordana F (2018) Monomer release from orthodontic retentions: An in vitro study. Am J Orthod Dentofacial Orthop 153:248-254. https://doi. org/10.1016/j.ajodo.2017.06.021

40. Pfeifer CS (2017) Polymer-Based Direct Filling Materials. Dent Clin North Am 61:733-750. https://doi.org/10.1016/j.cden.2017. 06.002

41. Prins GS, Hu WY, Xie L, Shi GB, Hu DP, Birch L, Bosland MC (2018) Evaluation of Bisphenol A (BPA) Exposures on Prostate Stem Cell Homeostasis and Prostate Cancer Risk in the NCTRSprague-Dawley Rat: An NIEHS/FDA CLARITY-BPA Consortium Study. Environ Health Perspect 126:117001. https://doi.org/ 10.1289/EHP3953

42. Pulgar R, Olea-Serrano MF, Novillo-Fertrell A, Rivas A, Pazos P, Pedraza V, Navajas JM, Olea N (2000) Determination of bisphenol $\mathrm{A}$ and related aromatic compounds released from bis-GMA-based composites and sealants by high performance liquid chromatography. Environ Health Perspect 108:21-27. https://doi.org/10.1289/ ehp.0010821

43. Purushothaman D, Kailasam V, Chitharanjan AB (2015) Bisphenol A release from orthodontic adhesives and its correlation with the degree of conversion. Am J Orthod Dentofacial Orthop 147:29-36. https://doi.org/10.1016/j.ajodo.2014.09.013

44. Rezg R, El-Fazaa S, Gharbi N, Mornagui B (2014) Bisphenol A and human chronic diseases: current evidences, possible mechanisms, and future perspectives. Environ Int 64:83-90. https://doi.org/10. 1016/j.envint.2013.12.007

45. Rochester JR (2013) Bisphenol A and human health: a review of the literature. Reprod Toxicol 42:132-155. https://doi.org/10.1016/ j.reprotox.2013.08.008

46. Schonfelder G, Wittfoht W, Hopp H, Talsness CE, Paul M, Chahoud I (2002) Parent bisphenol A accumulation in the human maternal-fetal-placental unit. Environ Health Perspect 110:A703-707. https://doi.org/10.1289/ehp.110-1241091

47. Schweikl H, Schmalz G, Spruss T (2001) The induction of micronuclei in vitro by unpolymerized resin monomers. J Dent Res 80:1615-1620. https://doi.org/10.1177/00220345010800070401

48. Schweikl H, Spagnuolo G, Schmalz G (2006) Genetic and cellular toxicology of dental resin monomers. J Dent Res 85:870-877. https://doi.org/10.1177/154405910608501001

49. Schwengberg S, Bohlen H, Kleinsasser N, Kehe K, Seiss M, Walther UI, Hickel R, Reichl FX (2005) In vitro embryotoxicity assessment with dental restorative materials. J Dent 33:49-55. https://doi.org/10.1016/j.jdent.2004.08.001

50. Spahl W, Budzikiewicz H, Geurtsen W (1998) Determination of leachable components from four commercial dental composites by gas and liquid chromatography/mass spectrometry. J Dent 26:137-145

51. Sunitha C, Kailasam V, Padmanabhan S, Chitharanjan AB (2011) Bisphenol A release from an orthodontic adhesive and its correlation with the degree of conversion on varying light-curing tip distances. Am J Orthod Dentofacial Orthop 140:239-244. https://doi. org/10.1016/j.ajodo.2010.02.037

52. Tanaka K, Taira M, Shintani H, Wakasa K, Yamaki M (1991) Residual monomers (TEGDMA and Bis-GMA) of a set visible-lightcured dental composite resin when immersed in water. J Oral Rehabil 18:353-362

53. Van Landuyt KL, Nawrot T, Geebelen B, De Munck J, Snauwaert J, Yoshihara K, Scheers H, Godderis L, Hoet P, Van Meerbeek B (2011) How much do resin-based dental materials release? A metaanalytical approach. Dent Mater 27:723-747. https://doi.org/10. 1016/j.dental.2011.05.001

54. Vandenberg LN, Chahoud I, Heindel JJ, Padmanabhan V, Paumgartten FJ, Schoenfelder G (2010) Urinary, circulating, and tissue biomonitoring studies indicate widespread exposure to bisphenol 
A. Environ Health Perspect 118:1055-1070. https://doi.org/10. 1289/ehp.0901716

55. Vandenberg LN, Colborn T, Hayes TB, Heindel JJ, Jacobs DR, Jr., Lee DH, Shioda T, Soto AM, vom Saal FS, Welshons WV, Zoeller RT, Myers JP (2012) Hormones and endocrine-disrupting chemicals: low-dose effects and nonmonotonic dose responses. Endocr Rev 33:378-455. https://doi.org/10.1210/er.2011-1050

56. vom Saal FS, Akingbemi BT, Belcher SM, Birnbaum LS, Crain DA, Eriksen M, Farabollini F, Guillette LJ, Jr., Hauser R, Heindel JJ, Ho SM, Hunt PA, Iguchi T, Jobling S, Kanno J, Keri RA, Knudsen KE, Laufer H, LeBlanc GA, Marcus M, McLachlan JA, Myers JP, Nadal A, Newbold RR, Olea N, Prins GS, Richter CA, Rubin BS, Sonnenschein C, Soto AM, Talsness CE, Vandenbergh JG, Vandenberg LN, Walser-Kuntz DR, Watson CS, Welshons WV, Wetherill Y, Zoeller RT (2007) Chapel Hill bisphenol A expert panel consensus statement: integration of mechanisms, effects in animals and potential to impact human health at current levels of exposure. Reprod Toxicol 24:131-138. https://doi.org/10.1016/j.reprotox.2007. 07.005

57. Vom Saal FS, Nagel SC, Coe BL, Angle BM, Taylor JA (2012) The estrogenic endocrine disrupting chemical bisphenol A (BPA) and obesity. Mol Cell Endocrinol 354:74-84. https://doi.org/10.1016/j. mce.2012.01.001

58. Williams S (2004) Ghost peaks in reversed-phase gradient HPLC: a review and update. J Chromatogr A 1052:1-11

59. Yang X, Liu Y, Li J, Chen M, Peng D, Liang Y, Song M, Zhang J, Jiang G (2016) Exposure to Bisphenol AF disrupts sex hormone levels and vitellogenin expression in zebrafish. Environ Toxicol 31:285-294. https://doi.org/10.1002/tox.22043

60. Yang Y, Reichl FX, Shi J, He X, Hickel R, Hogg C (2018) Cytotoxicity and DNA double-strand breaks in human gingival fibroblasts exposed to eluates of dental composites. Dent Mater 34:201-208. https://doi.org/10.1016/j.dental.2017.10.002

61. Zhou Y, Wang Z, Xia M, Zhuang S, Gong X, Pan J, Li C, Fan R, Pang Q, Lu S (2017) Neurotoxicity of low bisphenol A (BPA) exposure for young male mice: Implications for children exposed to environmental levels of BPA. Environ Pollut 229:40-48. https://doi. org/10.1016/j.envpol.2017.05.043

Publisher's Note Springer Nature remains neutral with regard to jurisdictional claims in published maps and institutional affiliations. 